\title{
CONVERSION OF COAL FLY ASH GLASS INTO GLASS-CERAMICS BY CONTROLLED THERMAL TREATMENT
}

\author{
Biljana Angjusheva, Vojo Jovanov, Emilija Fidanchevski \\ Faculty of Technology and Metallurgy, Ss. Cyril and Methodius University, \\ Rudger Boshkovic 16, Skopje, Republic of North Macedonia \\ biljana@tmf.ukim.edu.mk
}

\begin{abstract}
Glass-ceramics were fabricated by controlled crystallization of glass vitrified without any additives from coal fly ash. The glass transition temperature $\left(T_{g}\right)$ and peak temperature $\left(T_{\mathrm{p}}\right)$ of the parent glass were $580^{\circ} \mathrm{C}$ and $1020^{\circ} \mathrm{C}$, respectively. The crystallization tendency of the parent glass was estimated by the Hruby-coefficient $\left(K_{\mathrm{H}}=2.3\right)$. The ratio of the crystalline and amorphous phases in the glass-ceramics sintered at $1100{ }^{\circ} \mathrm{C} / 60 \mathrm{~min}$ was $68 / 32$. The major crystalline phases were calcium aluminum silicate (anorthite) and hematite. The density, bending strength, and E-modulus of the glass-ceramics were 2.20 $\mathrm{g} / \mathrm{cm}^{3}, 78 \mathrm{MPa}$, and $32 \mathrm{GPa}$, respectively. The glass-ceramics can potentially be used as a construction material.
\end{abstract}

Keywords: coal fly ash; vitrification; parent glass; consolidation; glass-ceramics

\section{КОНВЕРЗИЈА НА СТАКЛОТО ОД ЈАГЛЕНОВА ЛЕТЕЧКА ПЕПЕЛ ВО СТАКЛО-КЕРАМИКА СО КОНТРОЛИРАН ТЕРМИЧКИ ТРЕТМАН}

Од јагленова летечка пепел е добиена стакло-керамика со контролирана кристализација на витрифицирано стакло без додатоци,. Температурите на трансформација на стаклото $\left(T_{g}\right)$ и температурата на пикот $\left(T_{\mathrm{p}}\right)$ на матичното стакло се $580{ }^{\circ} \mathrm{C}$ и $1020^{\circ} \mathrm{C}$, соодветно. Тенденцијата за кристализација на матичното стакло беше проценета со коефициентот на Hruby $-\left(K_{\mathrm{H}}=2,3\right)$. Односот на кристалната спрема аморфната фаза во стакло-керамика синтерувана на $1100{ }^{\circ} \mathrm{C} / 60$ $\min$ изнесува $68 / 32$. Главната кристална фаза е калциум алуминиум силикат (анортит) и хематит. Густината, јачината на свиткување и Е-модулот на стакло-керамиката беше, соодветно, 2,20 $\mathrm{g} / \mathrm{cm}^{3}, 78 \mathrm{MPa}$ и $32 \mathrm{GPa}$. Стакло-керамиката има потенцијал да биде искористена како конструкциски материјал.

Клучни зборови: јагленова летечка пепел; витрификација; матично стакло-консолидација; стакло-керамика

\section{INTRODUCTION}

Fly ash is a residue or by-product of burning pulverized coal in thermal power plants. In the process of the combustion of coal, large quantities of fly ash are produced [1]. According to the European statistics for 2016 [2], about $64 \%$ of the total production in the EU belongs to fly ash, of which only $40 \%$ are used, most often in the cement industry as supplements in cement [3] or concrete production [4]. Coal is a dominant resource for the production of electricity in the Republic of North Macedonia, where more than $80 \%$ of the electrical power requirements are generated from REK Bitola, the largest lignite power plant located in nearby Bitola [5]. Currently, fly ash is used only in the cement industry in quantities smaller than the European statistics, and the rest ends up in a landfill near the thermal power plant. Therefore, urgent new applications of fly ash are needed in various 
fields. Glass-ceramics are one of the possibilities where a large volume of fly ash can be utilized [611]. Glass-ceramics are polycrystalline materials formed by controlled crystallization of suitable glasses during the specific heat treatment. There are several techniques and methodologies for obtaining glass-ceramics from coal fly ash: (i) The heat treatment of solid glass, which can be conventional (two-stage method) or modified conventional (one-stage), (ii) The controlled cooling of a molten glass, (iii) The sintering and crystallization of glass powders, etc. [12]. A detailed description of the methodologies for the synthesis of $\mathrm{CaO}-\mathrm{Al}_{2} \mathrm{O}_{3}$ $\mathrm{SiO}_{2}$ and $\mathrm{MgO}-\mathrm{Al}_{2} \mathrm{O}_{3}-\mathrm{SiO}_{2}$ systems of coal fly ash glass-ceramics is given in [11]. The authors reported the formation of a fine microstructure with nanocrystals, which is beneficial for the mechanical and functional properties of glass-ceramics [11]. Bortoluzzi et al. [7] studied the vitrification mechanism to immobilize hazardous elements and to transform them into glass-ceramics containing crystalline phases with high chemical and mechanical properties. Coal fly ash [13] was fully used to produce sintered glass-ceramics by direct sintering of $100 \%$ fly ashes with different particle sizes. The final product meets the standards for building decoration and provides the utilization of fly ash on a large scale with a high utilization rate and low energy consumption. Glass-ceramics [9] with densities of 2.607-2.739 $\mathrm{g} / \mathrm{cm}^{3}$, a Vickers hardness above $600 \mathrm{MPa}$, and an E-modulus of $96 \mathrm{GPa}$ were obtained from fly ash, rise husk ash, and calcium hydroxide by sintering glass obtained from melting and quenching of raw materials. The authors found that the ratio of $\mathrm{CaO} / \mathrm{SiO}_{2}$ and $\mathrm{SiO}_{2} / \mathrm{Al}_{2} \mathrm{O}_{3}$ contribute to the formation of anorthite and albite crystalline phases responsible for the final properties of the material. Barbieri et al. [14] reported the production of glass-ceramics from fly ash mixed with different by-products and dolomite. They developed several mixtures with different chemical compositions, but the three main oxides were the members of the $\mathrm{CaO}-\mathrm{Al}_{2} \mathrm{O}_{3}-\mathrm{SiO}_{2}$ systems. Glassceramics were obtained from fly ash and $40 \mathrm{wt} . \%$ waste glass at $1000{ }^{\circ} \mathrm{C} / 1 \mathrm{~h}$ with a bending strength of $63 \mathrm{MPa}$ and an E-modulus of $30 \mathrm{GPa}$. The density and porosity were $2.18 \mathrm{~g} / \mathrm{cm}^{3}$ and $14.3 \%$, respectively, and a relatively high value of shrinkage $(15.95 \%)$ was reported [6].

Each of the proposed techniques and methodologies reported in the literature has certain advantages or disadvantages. One of the main disadvantages of vitrification is the high energy consumption, but as a method, it has a huge advantage in terms of the immobilization of heavy and toxic elements either from the fly ash or other industrial wastes.

The aim of this paper is to fabricate glassceramics via vitrification of fly ash and controlled crystallization of the parent glass using a defined thermal treatment and to investigate the properties of the final product. This opens up the possibility of using coal fly ash from the Republic of North Macedonia in the construction industry.

\section{MATERIALS AND METHODS}

The fly ash used in this investigation was from the collection zone of the largest thermal power plant REK Bitola in the Republic of North Macedonia, coded as FA. Figure 1 presents the scheme of the processing route applied for the production of glass-ceramics.

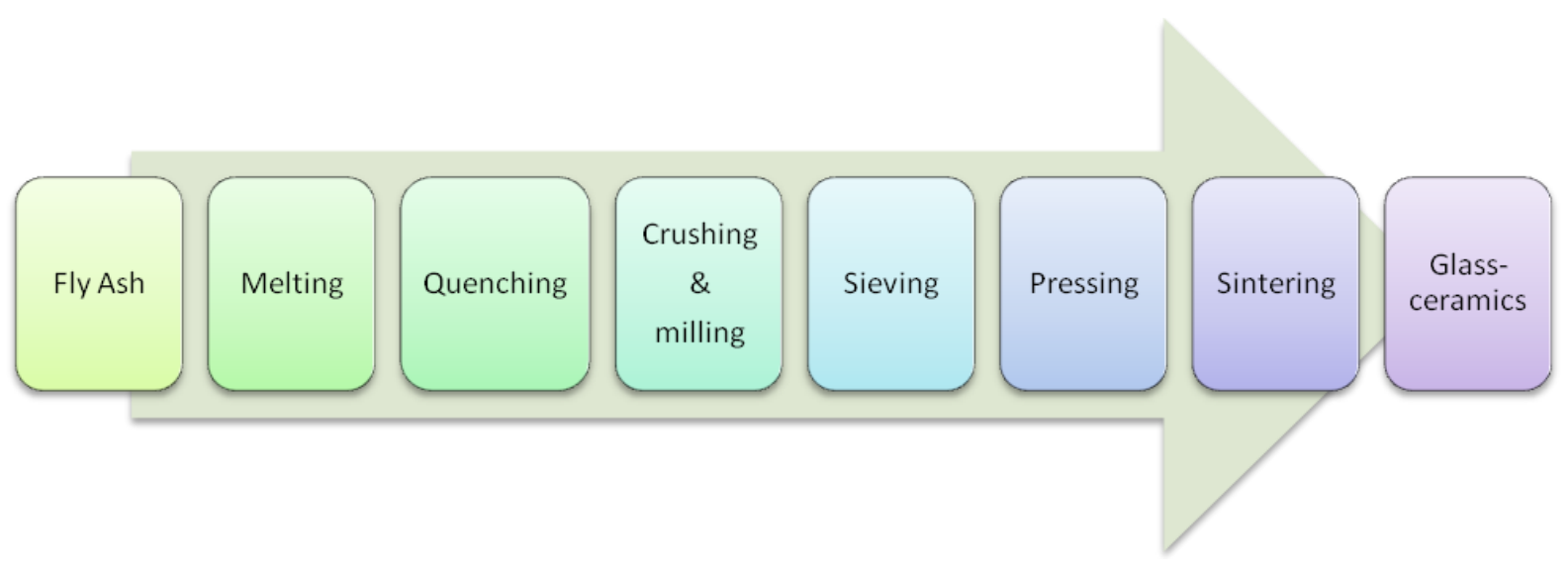

Fig. 1. Process scheme for glass-ceramics production from coal fly ash 


\subsection{Physical and thermal characterization of the fly ash (FA)}

The granulometric composition of the fly ash was determined by sieving analyses (Retsch AS200). The specific gravity of the fly ash was obtained by the pycnometer method. The specific surface area was defined using the BrunauerEmmett-Teller (BET) method (Micromeritcs, Gemini). The moisture content was calculated by the relationship: $\% m c_{\mathrm{wb}}=\left(m_{\mathrm{w}}-m_{\mathrm{d}} / m_{\mathrm{w}}\right) \times 100$, where $m c_{\mathrm{wb}}$ is expressed in the wet basis (where $m_{\mathrm{w}}$ is the mass of the wet fly ash and $m_{\mathrm{d}}$ is the mass of the dry fly ash).

The morphology of the fly ash was determined by using a scanning electron microscope (Leica S 440I).

The thermal characteristic of the fly ash was determined by an in situ heating optical microscope (Leitz Wetzlar) in the temperature interval of room temperature (RT) $-1400{ }^{\circ} \mathrm{C}$ in an air atmosphere using a heating rate of $10{ }^{\circ} \mathrm{C} / \mathrm{min}$. The experiments were performed on compacted samples with dimensions of $3 \mathrm{~mm} \times 3 \mathrm{~mm}$. The samples were prepared by uniaxial pressing of the FA powder using approximately $3 \%$ water. The compacts were introduced at room temperature into the furnace of the microscope. Images were taken using a camera at intervals of 1 min during the whole sintering process.

\subsection{Chemical and mineralogical composition of the fly ash (FA)}

The chemical composition of the fly ash was carried out by X-ray fluorescence (model ARL 9900). The unburned carbon content was determined from the loss of ignition (LOI) on a dried sample heated for $2 \mathrm{~h}$ at $900{ }^{\circ} \mathrm{C}$. The phase analysis was performed by XRD (Philips X-ray diffraction unit, Model PV 105-1) operating at $\mathrm{CuK}_{\alpha}$-radiation at an accelerating voltage of $40 \mathrm{kV}$ and a current of $40 \mathrm{~mA}$.

\subsection{Melting, quenching, crushing, and milling of glass from fly ash}

Glass (GFA) was obtained by melting the fly ash at $1450-1500{ }^{\circ} \mathrm{C}$ for $2 \mathrm{~h}$ in the graphite molds using an electrically heated furnace. To ensure homogeneity, quenching was applied, i.e. the melted glass was poured into water. The obtained glass was crushed and milled in a ball mill for $30 \mathrm{~min}$. A glass granulation less than $0.063 \mathrm{~mm}$ was used. The glass transition $\left(T_{\mathrm{g}}\right)$, peak temperature $\left(T_{\mathrm{p}}\right)$, and melting $\left(T_{\mathrm{m}}\right)$ temperature were detected by differential thermal analysis (DTA) (NETZSCH STA 409PC/PG) in an air atmosphere.

\subsection{Consolidation of the glass powder}

Consolidation of the parent glass was performed by uniaxial pressing at $P=45 \mathrm{MPa}$ (Weber Pressen KIP 100) and sintering in the chamber furnace at sintering temperatures of $800,850,900$, $950,1000,1050,1100^{\circ} \mathrm{C}$ using a heating rate of 10 ${ }^{\circ} \mathrm{C} / \mathrm{min}$. The isothermal period at the final temperatures was 30, 60, and $120 \mathrm{~min}$. Cooling was not controlled. The parent glass was pressed using a binder (5\% water) and coded as GCFA-T-time of isothermal treatment.

\subsection{Characterization of the glass-ceramics}

The bulk density was determined from the ratio of the weight and volume of the sintered glass-ceramics (GCFA). The shrinkage (\%) was estimated from the differences of the green and fired sample lengths. The porosity of the glassceramics was calculated from the relative density. The mineral composition of the parent glass and glass-ceramics was determined on selected samples sintered at 1000,1050 , and $1100{ }^{\circ} \mathrm{C} / 60 \mathrm{~min}$ by XRD (Philips X-ray diffraction unit, Model PV 105-1) operating at $\mathrm{CuK}_{\alpha}$-radiation at an accelerating voltage of $40 \mathrm{kV}$ and a current of $40 \mathrm{~mA}$.

The microstructure of the sintered glassceramics was assessed using scanning electron microscopy (SEM, Leica S440I) on gold-coated surfaces of selected glass-ceramic samples. The mechanical properties of the glass-ceramics (bending strength and E-modulus) were measured on test bars of dimensions $50 \mathrm{~mm} \times 4 \mathrm{~mm} \times 4 \mathrm{~mm}$. The samples were subjected to a 3-point bending strength test (Netzsch 401/3) with $30 \mathrm{~mm}$ span and $0.5 \mathrm{~mm} / \mathrm{min}$ loading rate.

For these mechanical tests, at least three samples were used per each mentioned type, and the results were averaged.

The chemical durability of the glass-ceramics was investigated by weight loss employing 0.1 $\mathrm{mol} / \mathrm{dm}^{3} \mathrm{HCl}, 0.1 \mathrm{~mol} / \mathrm{dm}^{3} \mathrm{Na}_{2} \mathrm{CO}_{3}$, and distilled water at room temperature after $24 \mathrm{~h}, 168 \mathrm{~h}$, and 720 h (DIN EN 106).

\section{RESULTS AND DISCUSSION}

\subsection{Characterization of the fly ash (FA)}

Table 1 presents the granulometric composition of the FA. More than $40 \mathrm{wt} . \%$ of particles with dimensions less than $63 \mu \mathrm{m}$ is evident. 
Table 1

Granulometric composition of FA

\begin{tabular}{cc}
\hline \hline $\begin{array}{c}\text { Sieve diameter } \\
{[\mathbf{m m}]}\end{array}$ & $\begin{array}{c}\boldsymbol{F A} \\
{[\boldsymbol{w t} . \%]}\end{array}$ \\
\hline+1.0 & 0.6 \\
$-1.0+0.5$ & 2.20 \\
$-0.5+0.25$ & 9.10 \\
$-0.25+0.125$ & 18.90 \\
$-0.125+0.063$ & 24.90 \\
$-0.063+0.045$ & 43.60 \\
\hline$\Sigma$ & 99.3 \\
\hline \hline
\end{tabular}

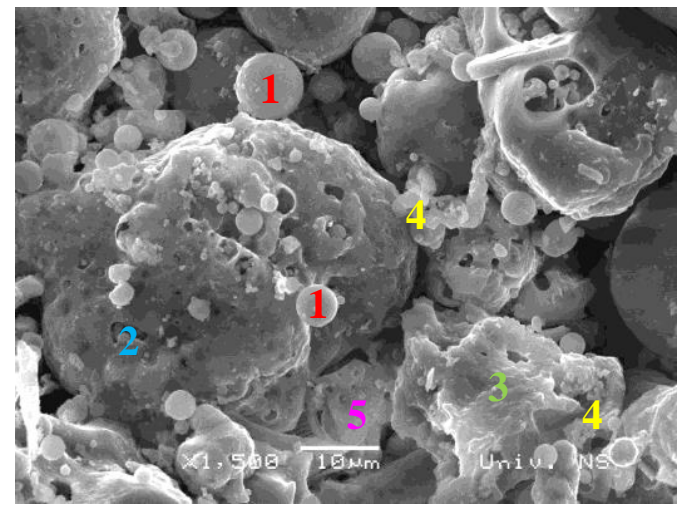

a)

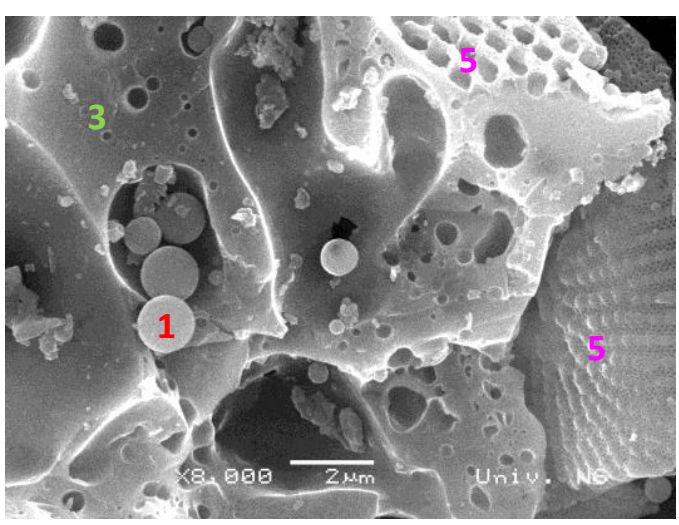

b)

Fig. 2. Morphology of fly ash, a) $\times 1500$, bar $10 \mu \mathrm{m}$; b) $\times 8000$, bar $2 \mu \mathrm{m}$

Figure 2 shows the typical morphology of fly ash. It is evident that there is the presence of sphere particles with dimensions less than $8 \mu \mathrm{m}$ (1), hollow spheres (2), and particles with irregular geometry and dimensions (3). Also, different sized agglomerates (4) are present in the fly ash. Honeycomb particles (5) are also evident, most likely from the diatoms present in the ash. The physical and thermal properties of the fly ash are shown in Table 2. The specific gravity and specific surface area of the investigated fly ash was $2.28 \mathrm{~g} / \mathrm{cm}^{3}$ and
$3.02 \mathrm{~m}^{2} / \mathrm{g}$, respectively. The results from the heating microscope in Figure 3 indicate that the melting of fly ash has to be at temperatures above 1300 ${ }^{\circ} \mathrm{C}$ to ensure the adequate viscosity of the melt. Dark brown glass was obtained after melting and quenching of fly ash, as described in [16].

Table 2

\section{Physical and thermal characteristics of fly ash}

\begin{tabular}{lc}
\hline \hline Characteristics & FA \\
\hline Specific surface area, $\left[\mathrm{m}^{2} / \mathrm{g}\right]$ & 3.02 \\
Moisture content, $[\mathrm{wt} . \%]$ & 1.34 \\
Specific gravity, $\left[\mathrm{g} / \mathrm{cm}^{3}\right]$ & 2.28 \\
Significant shrinkage $\left[{ }^{\circ} \mathrm{C}\right]$ & 1190 \\
Softening temperature $\left[{ }^{\circ} \mathrm{C}\right]$ & 1240 \\
Melting temperature $\left[{ }^{\circ} \mathrm{C}\right]$ & 1300 \\
\hline \hline
\end{tabular}

The chemical analysis of the fly ash shows a relatively high content of $\mathrm{SiO}_{2}$ and $\mathrm{Al}_{2} \mathrm{O}_{3}$ followed by $\mathrm{CaO}$ and $\mathrm{Fe}_{2} \mathrm{O}_{3}$ and smaller amounts of other alkaline and earth alkaline oxides. According to [17], if coal ash does not contain proper ratios of materials for the formation of a glass, additives may be needed. Little et al. [18] classified the constituent oxides as network constituents - $\mathrm{SiO}_{2}$, network modifiers $-\mathrm{CaO}, \mathrm{MgO}, \mathrm{Na}_{2} \mathrm{O}, \mathrm{K}_{2} \mathrm{O}, \mathrm{P}_{2} \mathrm{O}_{5}$, and amphoteric $-\mathrm{Al}_{2} \mathrm{O}_{3}, \mathrm{Fe}_{2} \mathrm{O}_{3}$. A network constituent $\left(\mathrm{SiO}_{2}\right.$ present in this fly ash is more than 50 $\%)$ acts like constructs network blocks, forming long stable inorganic networks that are responsible for increasing the viscosity of the melt. Network modifiers (present in actual fly ash in a total quantity of $19.29 \mathrm{wt} . \%$ ) reduce the stability by forming non-bridging oxygen bonds in the structure, which have the effect of reducing the glass viscosity. Amphoteric oxides can react as network formers or as network modifiers depending on the composition of the melt. Although the network modifiers (such as alkali metals) may decrease the glass properties, they are important to control the melted glass viscosity and thermal behavior. The most effective glass modifier is $\mathrm{Na}_{2} \mathrm{O}$. Other than $\mathrm{CaO}$ or $\mathrm{MgO}$, adding $\mathrm{Na}_{2} \mathrm{O}$ will not increase the crystalline tendency.

The mineralogical composition of fly ash was quartz, anorthite, albite, hematite, anhydrite, and amorphous phase. According to [19], the fraction of glass in fly ash varies in the range from 70 to 89 wt.\% depending on the type of coal that is used, the degree of pulverization, the combustion conditions in the furnace, and the cooling rate of the combustion residue. 


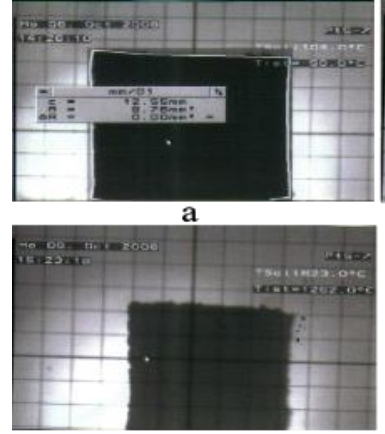

e

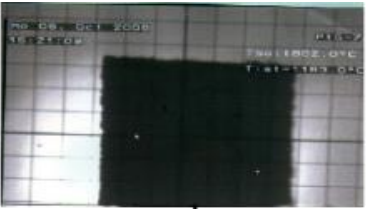

b

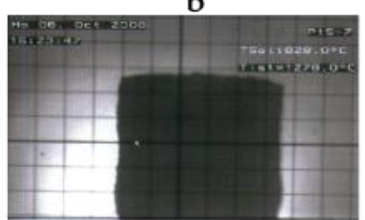

f

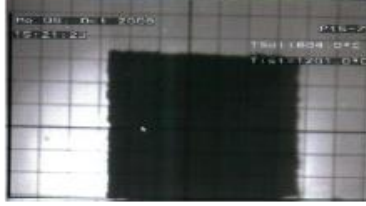

c

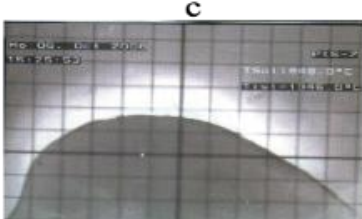

$\mathrm{g}$
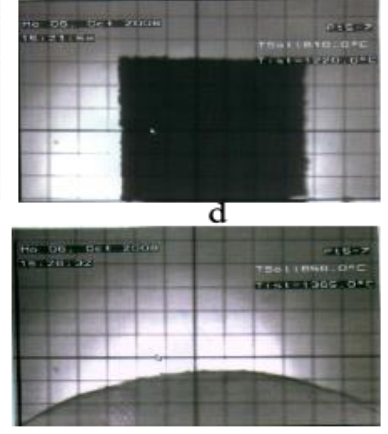

h

Fig. 3. Typical sequence of images of a sintering fly ash obtained with the heating microscope: $\mathrm{a}-50{ }^{\circ} \mathrm{C}, \mathrm{b}-1190{ }^{\circ} \mathrm{C}, \mathrm{c}-1200{ }^{\circ} \mathrm{C}, \mathrm{d}-1220{ }^{\circ} \mathrm{C}, \mathrm{e}-1260^{\circ} \mathrm{C}, \mathrm{f}-1280{ }^{\circ} \mathrm{C}, \mathrm{g}-1345^{\circ} \mathrm{C}, \mathrm{h}-1365^{\circ} \mathrm{C}$

T a b l e 3

Chemical composition of the FA

\begin{tabular}{ccccccccccc}
\hline \hline Oxide & $\mathbf{S i O}_{2}$ & $\mathbf{A l}_{2} \mathbf{O}_{3}$ & $\mathbf{F e}_{2} \mathbf{O}_{3}$ & $\mathbf{C a O}$ & $\mathbf{M g O}$ & $\mathbf{N a}_{2} \mathbf{O}$ & $\mathbf{K}_{2} \mathbf{O}$ & $\mathbf{S O}_{3}$ & $\mathbf{L O I}$ & $\boldsymbol{\Sigma}$ \\
\hline FA [wt.\%] & 50.33 & 18.59 & 7.71 & 13.76 & 3.05 & 1.07 & 1.41 & 1.41 & 2.60 & 99.96 \\
\hline \hline
\end{tabular}

\subsection{Thermal characteristics of the parent glass} (GFA)

The DTA curve in Figure 4 depicts the thermal behavior (including $T_{\mathrm{g}}, T_{\mathrm{p}}$, and $T_{\mathrm{m}}$ ) of the parent glass GFA with a granulation less than $63 \mu \mathrm{m}$. The finesse of the particles directly influences the sintering ability and properties of the glass-ceramics, where the driving force in the sintering process is the surface energy of the powder. Fine particles of the parent glass imply a low sintering temperature, high strength, and smooth surface of the final product [13].

Figure 4 illustrates that the transformation temperature of the glass $\left(T_{\mathrm{g}}\right)$ is at $580{ }^{\circ} \mathrm{C}$, and the exo-peak of crystallization $\left(T_{\mathrm{p}}\right)$ occurs at $1020^{\circ} \mathrm{C}$, suggesting that the crystallization process is in- tense within the temperature range of 900-1050 ${ }^{\circ} \mathrm{C}$. Barbieri et al. [20] reported that these exoeffects are typical for glass with a high crystallization tendency. The endo effect refers to glass melting $\left(\mathrm{T}_{\mathrm{m}}\right)$, which appears at $1220^{\circ} \mathrm{C}$. Based on the above results, the maximal crystallization of glass obtained by fly ash melting occurs in the temperature range from $900{ }^{\circ} \mathrm{C}$ to $1200{ }^{\circ} \mathrm{C}$.

The ratio of the glass transition to the melting temperature, $T_{\mathrm{g}} / T_{\mathrm{m}}$, identifies the crystallization process. Namely, crystallization has a bulk mechanism if $T_{\mathrm{g}} / T_{\mathrm{m}}$ is lower than 0.58 , but if it is higher, the crystallization has a surface mechanism [21]. The investigated parent glass has a bulk mechanism of crystallization $\left(T_{\mathrm{g}} / T_{\mathrm{m}}=0.47\right)$.

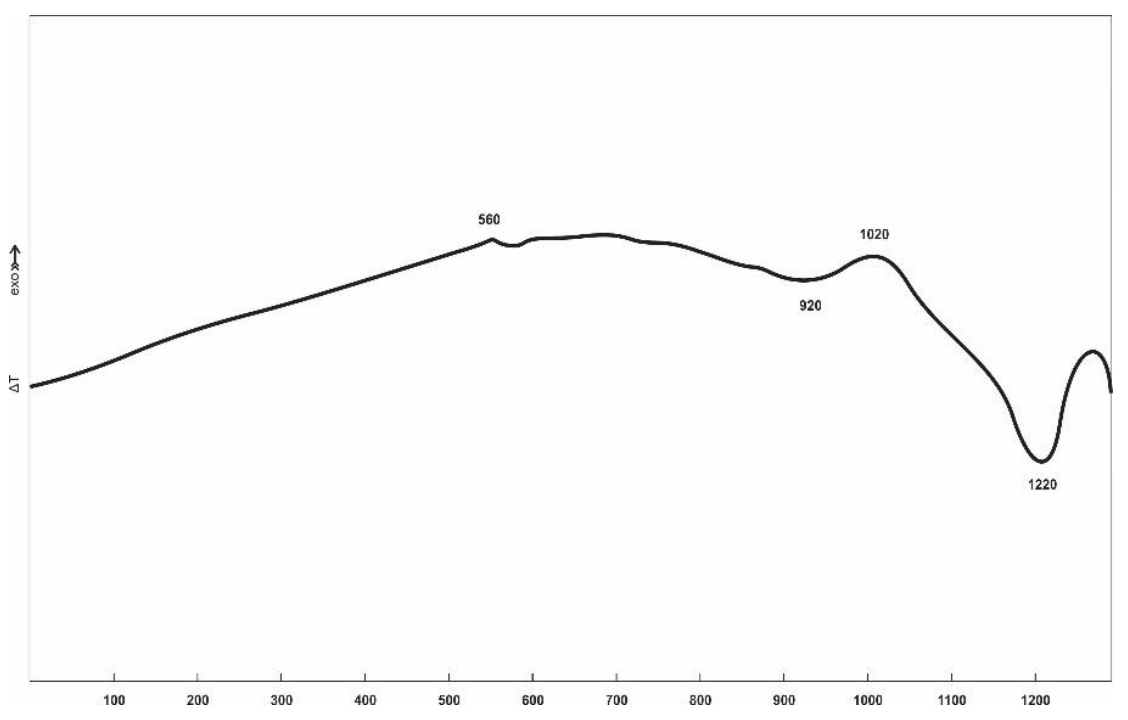

Fig. 4. DTA curve of GFA 
The Hruby coefficient, $K_{\mathrm{H}}=\left(T_{\mathrm{p}}-T_{\mathrm{g}}\right) /\left(T_{\mathrm{m}}-T_{\mathrm{p}}\right)$ is used to process the glass crystallization capacity. The higher the coefficient value $\left(K_{\mathrm{H}}\right)$, the lower the crystallization tendency [21]. The $K_{\mathrm{H}}$ obtained from the DTA curves is 2.3 , confirming the high tendency for crystallization of the parent glass GFA.

\subsection{Mineralogical composition of the parent glass (GFA) and glass-ceramics (GCFA)}

The mineralogical behavior of the parent glass in the investigated thermal treatment was followed by XRD analysis (Figs. 5, 6, and 7). An almost totally amorphous phase of the parent glass is presented in the XRD pattern at $25^{\circ} \mathrm{C}$ (Fig. 5), but the presence of a crystalline phase occurs at $580{ }^{\circ} \mathrm{C}$ (Fig. 6), particularly anorthite, a crystalline phase belonging to the feldspar mineral group, and hematite. The predominant crystalline phase is anorthite, while the secondary phase is hematite, although it is difficult to determine the correct ratio because of the overlapping peaks. Francis et al. [22] pointed out that glass-ceramics are a complex system where the crystalline phases are not of simple stoichiometry, and complicated reactions might occur that could lead to changes in the composition with time and temperature. Figure 7 illustrates the progress of the crystallinity of glass-ceramics at the evaluated temperatures of 1000, 1050, and 1100 ${ }^{\circ} \mathrm{C} / 60 \mathrm{~min}$.

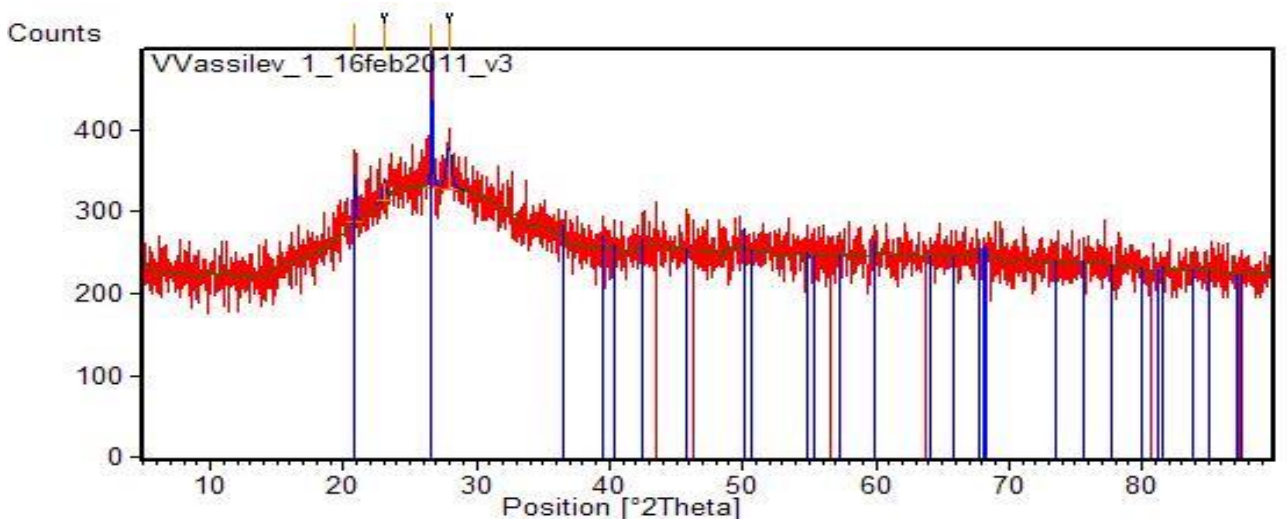

Fig. 5. XRD pattern of GFA, $T=25^{\circ} \mathrm{C}$

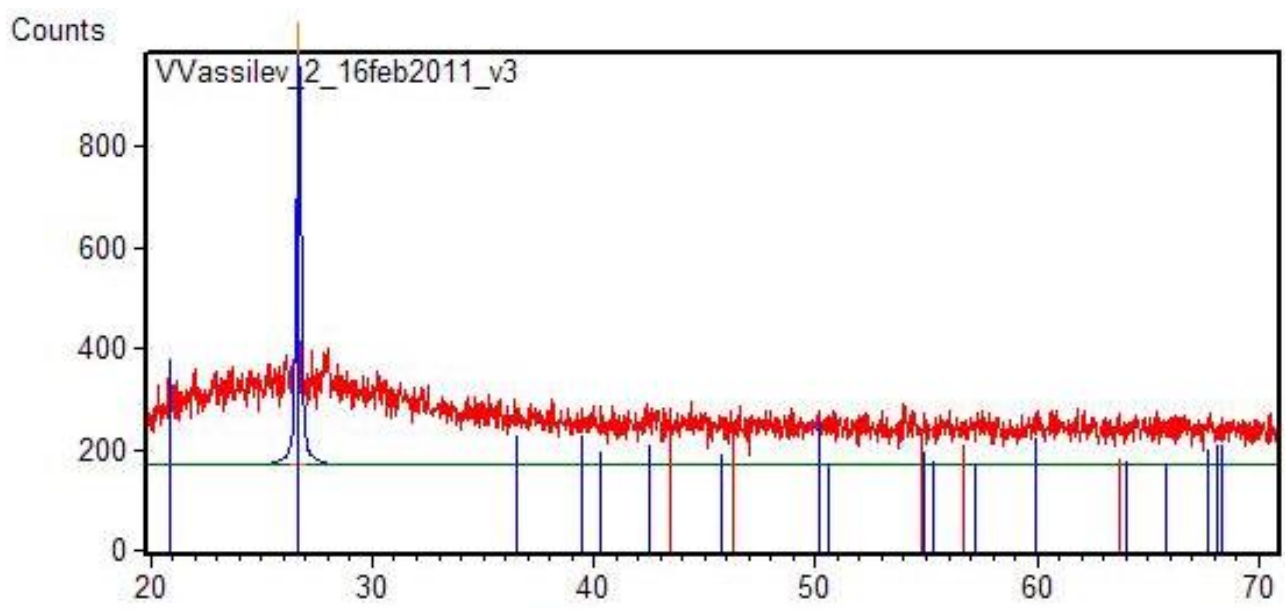

Fig. 6. XRD pattern of GCFA, $T=580^{\circ} \mathrm{C}$

The amounts of the crystalline and amorphous phases for each thermal treatment studied by XRD are shown in Figure 8. It shows that by increasing the temperature, the crystallinity increases. The crystalline phase at $1000{ }^{\circ} \mathrm{C} / 60 \mathrm{~min}$ is more than $60 \mathrm{wt} . \%$, reaching a maximum of $68 \mathrm{wt} . \%$ at $1100{ }^{\circ} \mathrm{C} / 60 \mathrm{~min}$. According to [21], GCFA-1100 ${ }^{\circ} \mathrm{C} / 60$ belongs to glass-ceramics with a high degree of crystallization (glass content in the range of 10$40 \mathrm{wt} . \%)$. 

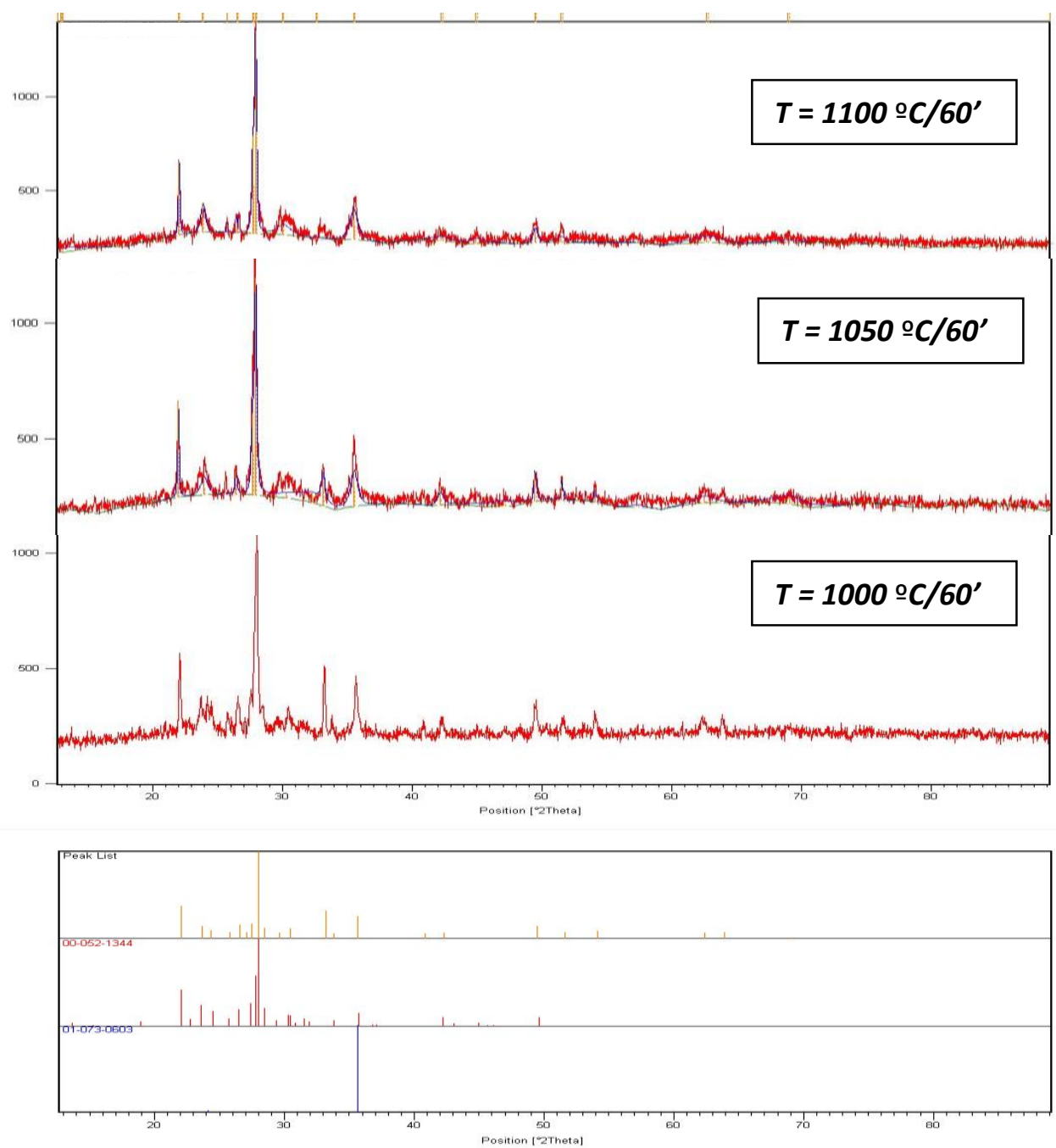

Fig. 7. XRD patterns of GCFA sintered at 1000,1050 , and $1100^{\circ} \mathrm{C} / 60 \mathrm{~min}$,

Phase 1: Calcium aluminum silicate 00-052-1344. Phase 2: Iron(III) oxide reference ICSD. 01-073-0603.

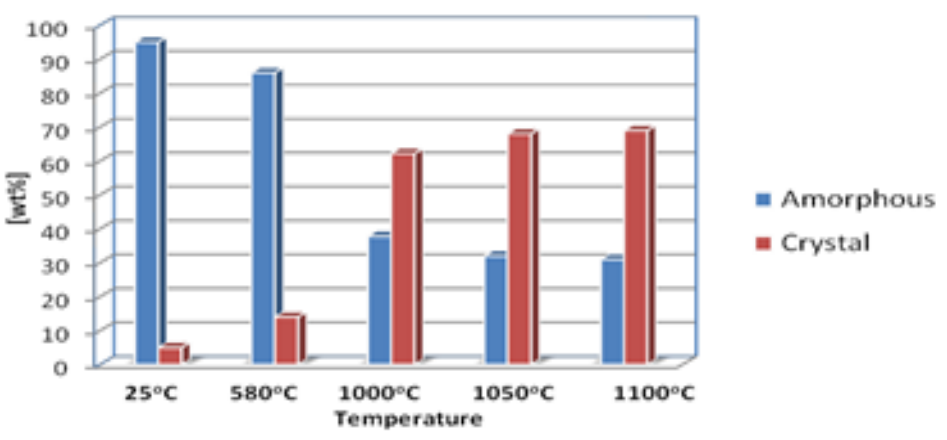

Fig. 8. The quantity of amorphous and crystalline phase in GFA and GCFA at defined temperatures with isothermal treatment of $60 \mathrm{~min}$

\subsection{Physical and mechanical properties of glass-ceramics}

The variation of the glass-ceramic density on defined temperature treatments is shown in Figure 9. There are no major differences in the glass- ceramic densities sintered at temperatures up to $1050{ }^{\circ} \mathrm{C}$, but a significant change occurs at 1100 ${ }^{\circ} \mathrm{C} / 60 \mathrm{~min}$ (the density increases from 1.60 to 2.20 $\mathrm{g} / \mathrm{cm}^{3}$ ). At $1100{ }^{\circ} \mathrm{C} / 120 \mathrm{~min}$, the geometrical deformation in the glass-ceramics was evident, but at the lowest temperatures, the isothermal period of 
$120 \mathrm{~min}$ at the final temperature did not have any influence on the geometry of the glass-ceramics. Density as a parameter is an indicator of the degree of sintering [23]. Since the glass density is an additive function of the chemical composition, the density of the crystal phases depends on their structure and packing [24].

Porosity (Fig. 10) is in direct correlation with glass-ceramic density. The most significant differences in porosity are detected for glassceramics sintered at $1100{ }^{\circ} \mathrm{C} / 60 \mathrm{~min}$, reaching the minimum value of $12.8 \%$.

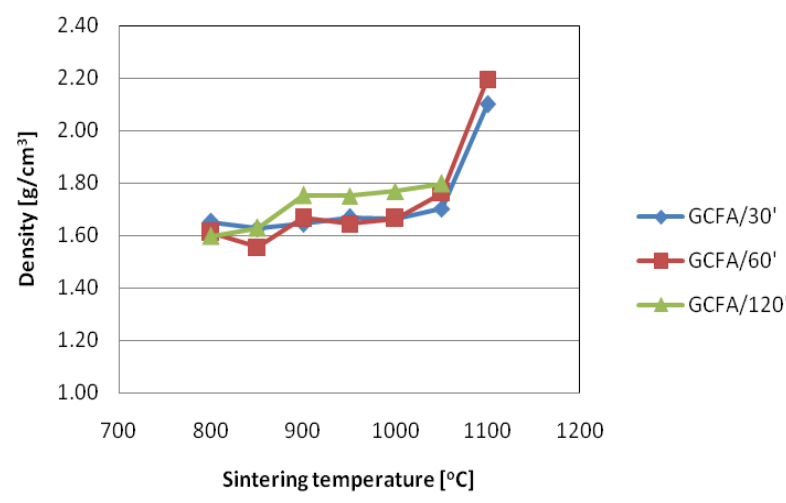

Fig. 9. Density of GCFA after exposure to defined temperature treatments.

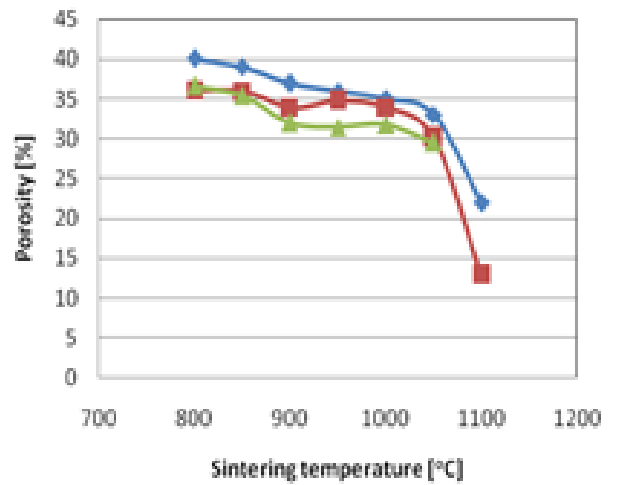

Fig. 10. Porosity of GCFA after exposure to defined temperature treatments

Also, the maximal shrinkage (12\%) of glass-ceramics is evident at $1100{ }^{\circ} \mathrm{C} / 60 \mathrm{~min}$ (Fig. 11). Ikeda et al. [25] showed that the trends in the linear shrinkage correlate with alkali and earth alkali ions and the amount of oxides. They reported the linear shrinkage in the range of $13-15 \%$ for glass-ceramics with different compositions of $\mathrm{CaO}$ and $\mathrm{Na}_{2} \mathrm{O}$ fired at temperatures from 1000 to1200 ${ }^{\circ} \mathrm{C}$ obtained from fly ash.

Figures 12 and 13 show that there are no significant differences in the mechanical properties for sintering temperatures in the range of 800 $1000{ }^{\circ} \mathrm{C}$. The degree of crystallization has a significant influence on the mechanical properties. The maximum values of the bending strength and Emodulus (78 MPa and $32 \mathrm{GPa}$ ) were achieved for glass-ceramics sintered at $1100{ }^{\circ} \mathrm{C} / 60 \mathrm{~min}$ where the crystallization rate was maximal at $68 \%$.

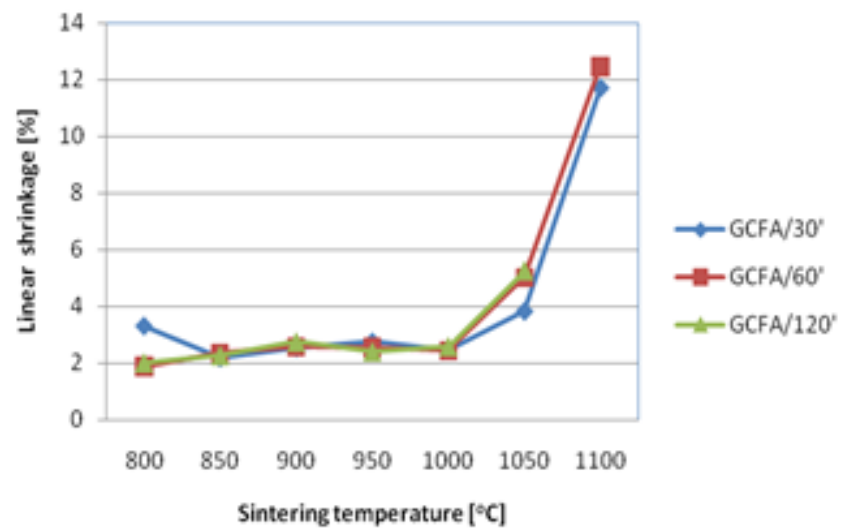

Fig. 11. Linear shrinkage of GCFA after exposure to defined temperature treatments

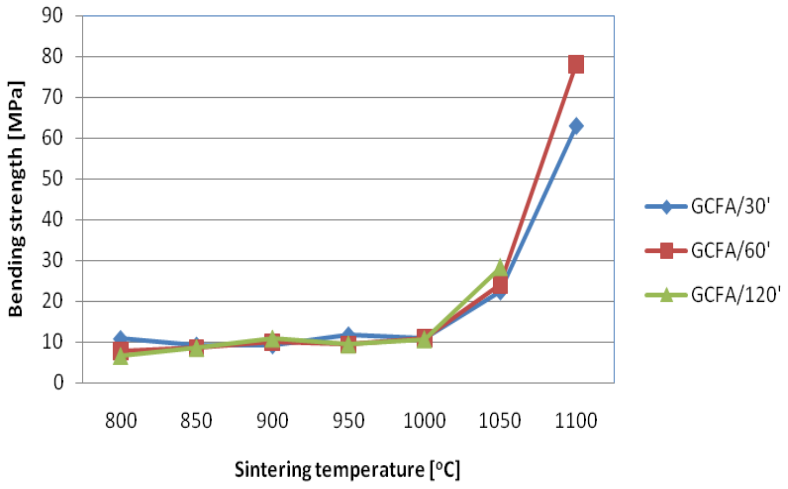

Fig. 12. Bending strength of GCFA after exposure to defined thermal treatments

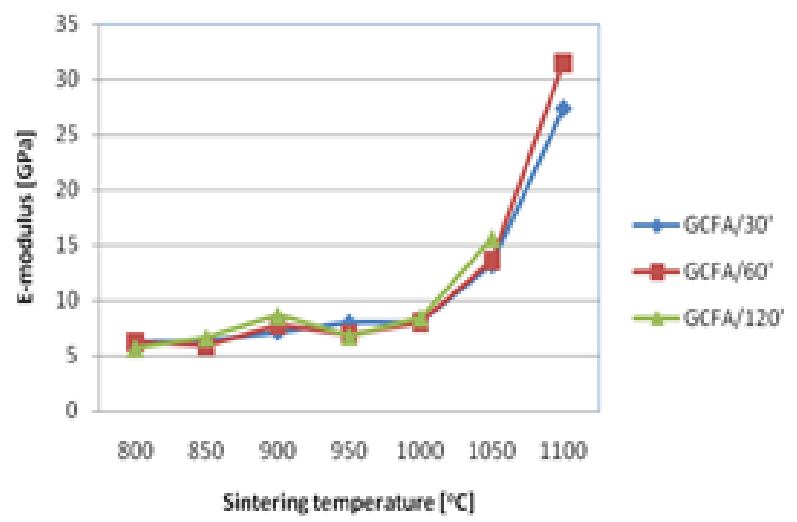

Fig. 13. E-modulus of GCFA after exposure to defined thermal treatments 
T a ble 4

Density and bending strength of some natural materials and glass-ceramics produced from fly ash.

\begin{tabular}{lccc}
\hline \hline Property & $\begin{array}{c}\text { Sintering } \\
\text { temperature } \\
{\left[{ }^{\circ} \mathbf{C}\right]}\end{array}$ & $\begin{array}{c}\text { Density } \\
{\left[\mathbf{g} / \mathbf{c m}^{3}\right]}\end{array}$ & $\begin{array}{c}\text { Bending } \\
\text { strength } \\
{[\mathbf{M P a}]}\end{array}$ \\
\hline GCFA/60' & 1100 & 2.20 & 78 \\
40CFA [13] & 1180 & 2.35 & 55 \\
FNA8254 [26] & 825 & 2.59 & $63 \pm 6$ \\
HGC1/C2 [27] & 1150 & $1.8-1.99$ & $26-40$ \\
Marble [28] & $/$ & $2.6-2.8$ & $14-17$ \\
Granite [28] & $/$ & $2.6-2.8$ & $12-15$ \\
\hline \hline
\end{tabular}

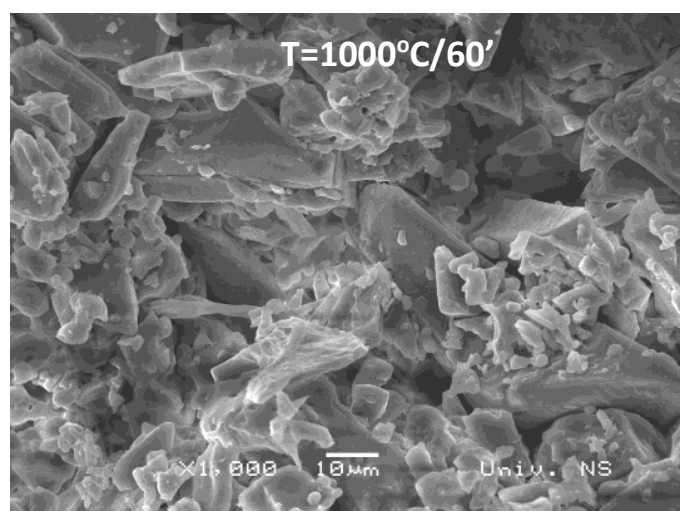

(a), (bar 10 $\mu \mathrm{m})$

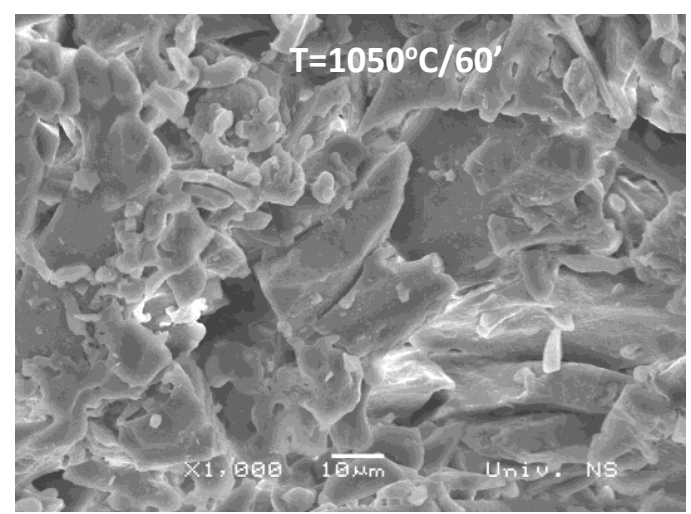

(c), (bar 10 $\mu \mathrm{m})$

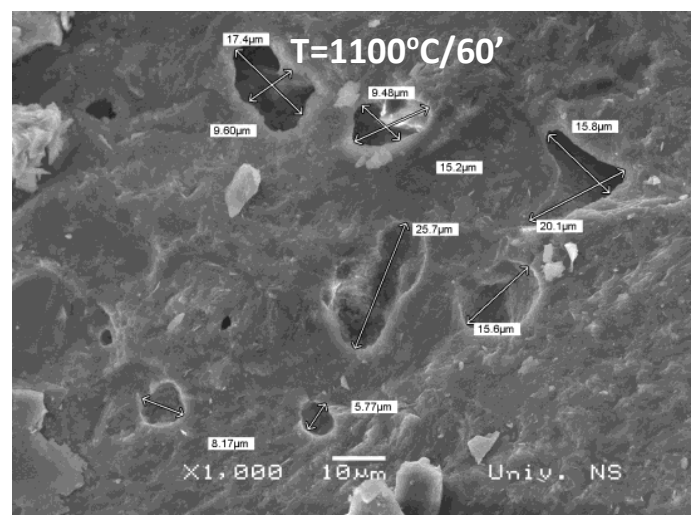

(e), (bar 10 $\mu \mathrm{m})$
Table 4 presents the density and bending strength of glass-ceramics obtained by vitrification of coal fly ash as well as from some natural materials like marble and granite. The results of GCFA sintered at $1100{ }^{\circ} \mathrm{C} / 60 \mathrm{~min}$ are comparable to those reported in the literature.

\subsection{Microstructure of the glass-ceramics}

The microstructure development of the glass ceramics sintered at 1000,1050 , and $1100{ }^{\circ} \mathrm{C} / 60$ $\min$ is presented in Figure 14.

Figures 14 (a) and (b) show that the fractured surface is rough, and grains with various geometries with sharp edges are present.

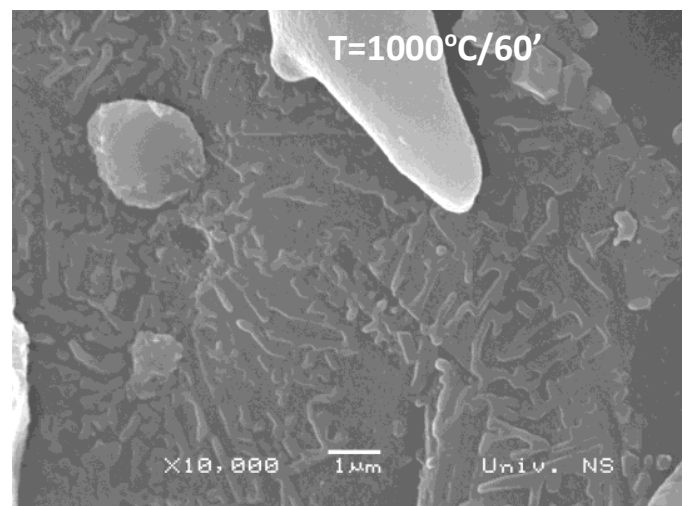

(b), (bar $1 \mu \mathrm{m})$

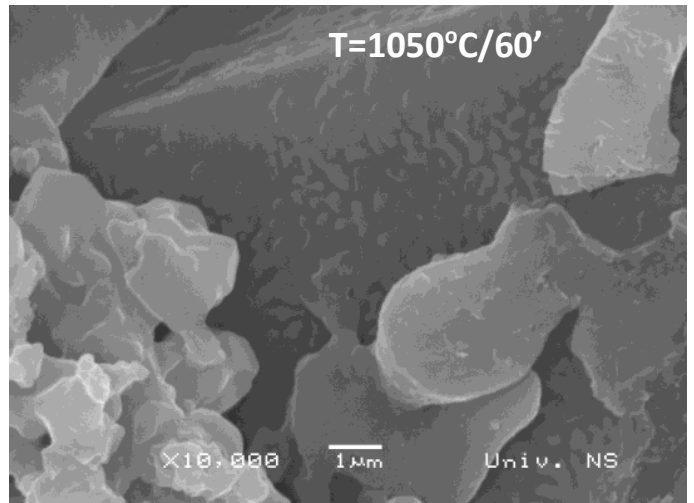

(d), (bar $1 \mu \mathrm{m})$

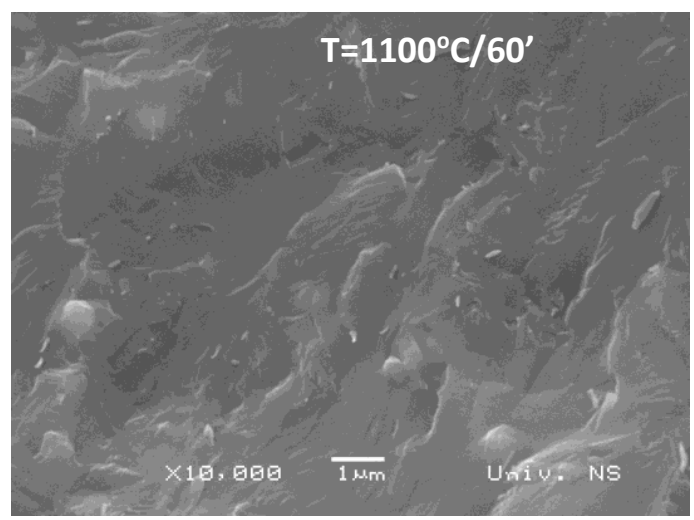

(f), (bar $1 \mu \mathrm{m})$

Fig. 14. SEM micrographs of a fractured GCFA sample 
Pores with undefined geometry and dimension are also noticeable. At a greater magnification of $10,000 \times(b)$, dendritic crystals with a size less than $1 \mu \mathrm{m}$ are noticeable. Large-sized smoothwalled grains are also seen, most likely coming from the glassy phase. The energy-dispersive Xray spectroscopy (EDS analysis) of the glassceramics shown in Figure 15 points to the fact that it is a structure that chemically corresponds to the detected alumino-silicates. Also, the presence of a hematite phase was confirmed by XRD analysis. The surface of the fractured glass-ceramics sintered at $1050{ }^{\circ} \mathrm{C} / 60 \mathrm{~min}$ is smoother (Figs. 14 (c) and (d)) in comparison to the previous structure of glass-ceramics sintered at a lower temperature. The dendritic forms are rounded, and the presence of porous particles (Fig. 16) are observed. The EDS analysis confirms that these are hematite particles associated with calcium alumino-silicate (Fig. 16).
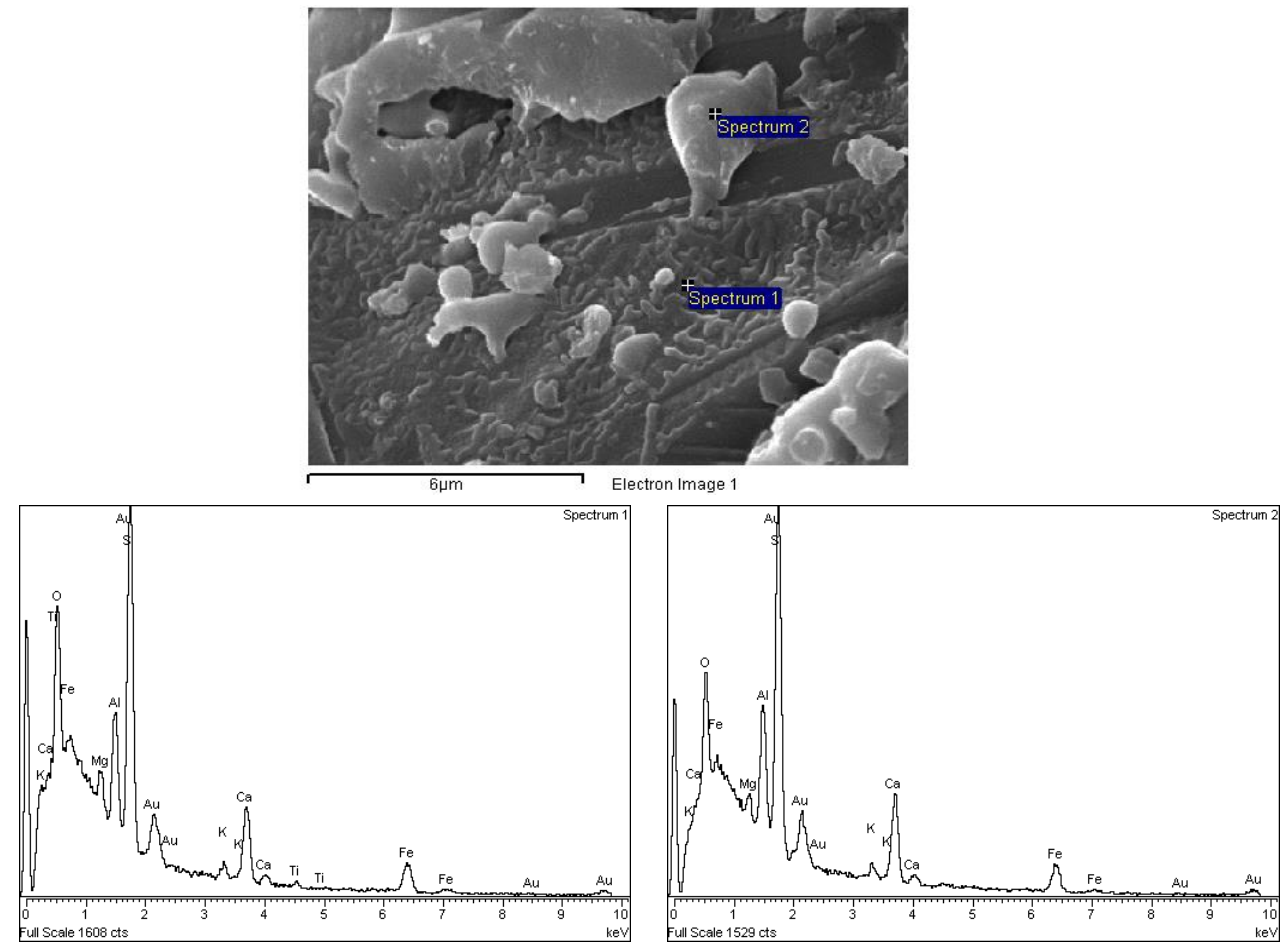

Fig. 15. EDS analysis of GCFA, $T=1000{ }^{\circ} \mathrm{C} / 60 \mathrm{~min}$

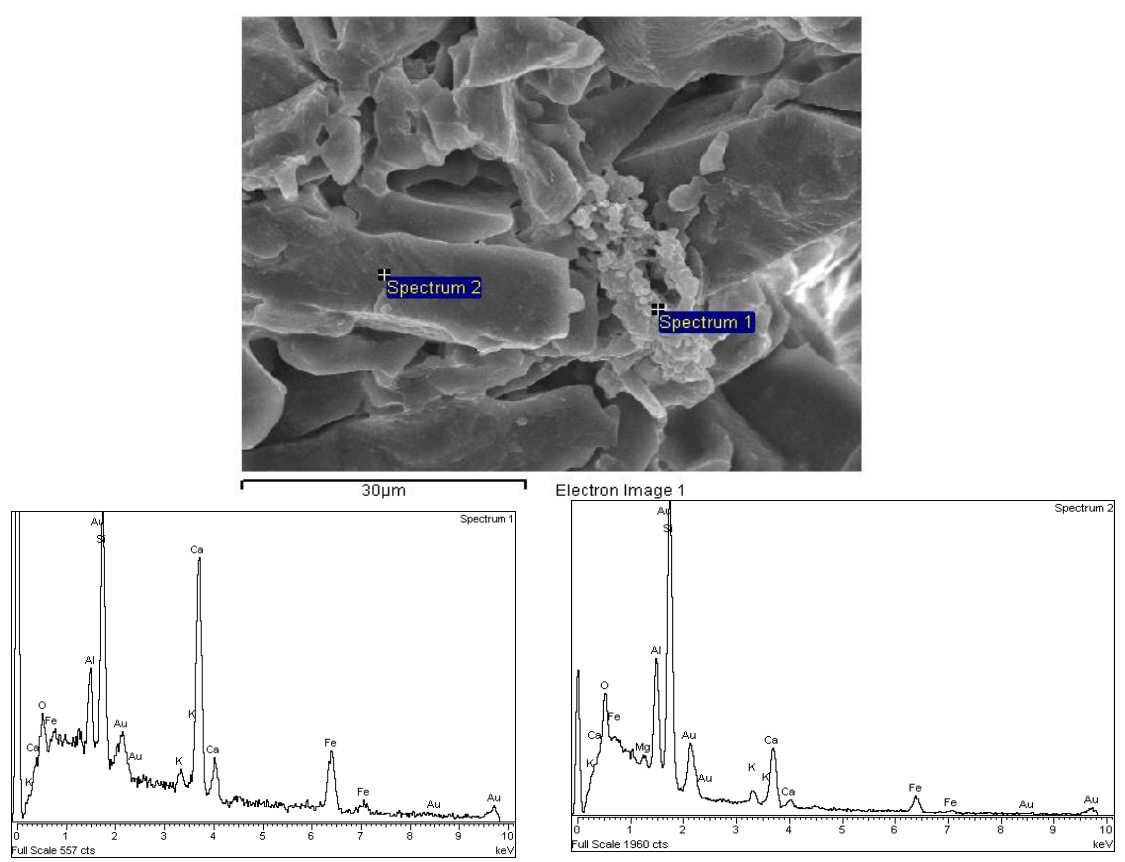

Fig. 16. EDS analysis of GCFA, $\mathrm{T}=1050^{\circ} \mathrm{C} / 60 \mathrm{~min}$. 
Figure 14 (e) and (f) present SEM micrographs of the fracture surface of compact GCFA sintered at $1100{ }^{\circ} \mathrm{C} / 1 \mathrm{~h}$. It can be seen (Fig. 14 (e)) that the surface is smooth and homogeneous and completely crystallized on which irregular unconnected pores with dimensions of 5-25 $\mu \mathrm{m}$ are formed. Smaller crystalline forms (Fig. 14(f)) can be seen on the walls of the pores with dimensions of 100-300 nm, (EDS analysis of the same sample (Fig. 17) indicates that (in Spectrum 2 and 3) there are no significant differences in the oxide composition. Inside the pores (Spectrum 1), there is an increased presence of iron from iron oxide, i.e. hematite.

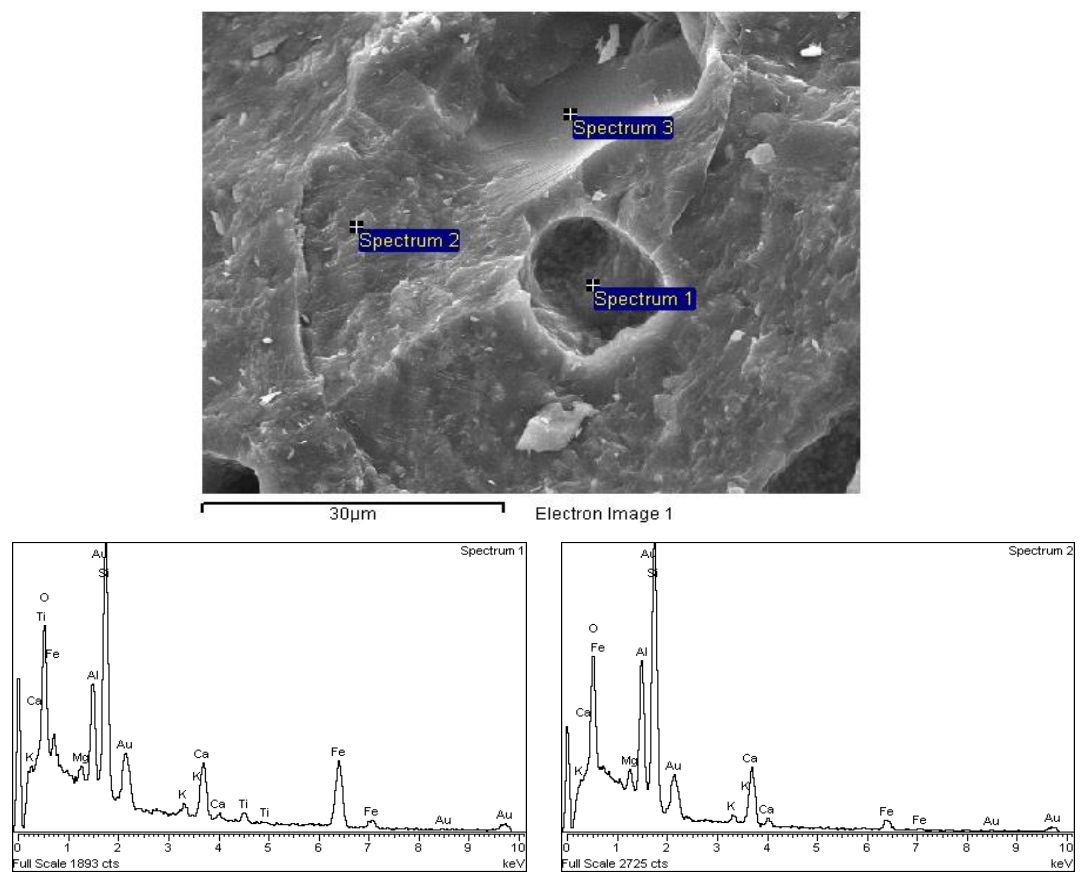

Fig. 17. EDS analysis of GCFA, $T=1100^{\circ} \mathrm{C} / 60 \mathrm{~min}$

\subsection{Durability of the glass-ceramics}

The results shown in Table 5 imply that all glass-ceramics had better resistance when soaked in water and an alkali solution then when soaked in an acidic solution. There are two mechanisms describing the solubility of glass-ceramics [29]. The first is ion-exchange leaching, which involves the replacement of $\mathrm{Na}^{+}$and $\mathrm{K}^{+}$with a hydrogenbearing ion from the solution, leading to the formation of a leached layer, i.e. alkali depleted layer. Therefore, in neutral and acid media, the initial stage of the reactions is the diffusion of alkali ions through the glass network into the solution.

Table 5

Chemical resistance of glass-ceramics in terms of mass loss (wt.\%)

\begin{tabular}{lccccc}
\hline \hline \multirow{2}{*}{ Solutions } & $\begin{array}{c}\text { Duration } \\
{[\mathrm{h}]}\end{array}$ & $\begin{array}{c}\text { GCFA } \\
950^{\circ} \mathrm{C} / 60\end{array}$ & $\begin{array}{c}\text { GCFA } \\
1000^{\circ} \mathrm{C} / 60\end{array}$ & $\begin{array}{c}\text { GCFA } \\
1050^{\circ} \mathrm{C} / 60\end{array}$ & $\begin{array}{c}\text { GCFA } \\
1100^{\circ} \mathrm{C} / 60\end{array}$ \\
\hline \multirow{3}{*}{$\mathrm{HCl}$} & 24 & 0.19 & 0.20 & 0.53 & 0.48 \\
& 168 & 2.01 & 2.03 & 1.6 & 1.43 \\
& 720 & 3.05 & 2.75 & 2.14 & 1.76 \\
$\mathrm{Na}_{2} \mathrm{CO}_{3}$ & 24 & 0.33 & 0.20 & 0.20 & 0.15 \\
& 168 & 0.37 & 0.31 & 0.24 & 0.20 \\
& 720 & 0.45 & 0.30 & 0.25 & 0.23 \\
\hline \multirow{3}{*}{$\mathrm{H}_{2} \mathrm{O}$} & 24 & 0.022 & 0.023 & 0.08 & 0.04 \\
& 168 & 0.023 & 0.07 & 0.05 & 0.03 \\
& 720 & 0.05 & 0.05 & 0.07 & 0.04 \\
\hline \hline
\end{tabular}


The second is a matrix dissolution reaction, which implies the dissolution of the Si-network, and glass dissolves directly into the solution either after leaching or without leaching. The data obtained in Table 5 are much lower than that reported in literature [30], especially in acid media, but more experiments are needed for a detailed description of the complex leaching process.

\section{CONCLUSION}

The fabrication of glass-ceramics without any additives from coal fly ash is demonstrated by establishing the processing route for treatment of the fly ash. Fly ash was vitrified, and glass-ceramics were obtained by controlled crystallization of the parent glass. The crystallization behavior of the parent glass revealed the glass transition temperature $\left(T_{\mathrm{g}}=580^{\circ} \mathrm{C}\right)$ and peak temperature $\left(T_{\mathrm{p}}=1020^{\circ} \mathrm{C}\right)$. The intense crystallization process can be conducted at the temperature range between 900 and $1050{ }^{\circ} \mathrm{C}$. The crystallization mechanism for the parent glass is of a bulk type based on the ratio $T_{\mathrm{g}} / T_{\mathrm{m}}(0.47)$. The high tendency for crystallization of the parent glass was confirmed by the Hruby coefficient $\left(K_{\mathrm{H}}=2.3\right)$. Glass ceramics with a density in the range of 1.6$1.8 \mathrm{~g} / \mathrm{cm}^{3}$ and a porosity from 40 to $30 \%$ were fabricated in the temperature interval $800-1050{ }^{\circ} \mathrm{C} / 30$, 60, and $120 \mathrm{~min}$, while the bending strength and Emodulus varied from 8 to $30 \mathrm{MPa}$ and from 6 to 15 $\mathrm{GPa}$, respectively. The maximal values of density $\left(2.2 \mathrm{~g} / \mathrm{cm}^{3}\right)$, bending strength $(78 \mathrm{MPa})$, and Emodulus (32 GPa) and minimal porosity $(12.8 \%)$ were achieved for glass-ceramics sintered at 1100 ${ }^{\circ} \mathrm{C} / 60 \mathrm{~min}$. The ratio of the crystalline and amorphous phases was $68 / 32$, and the major crystalline phases were calcium aluminum silicate (anorthite) and hematite. SEM/EDS analysis confirmed that the crystals were homogeneously dispersed within the glass matrix. The obtained glass-ceramics can be potentially used as a substitute for traditional materials in construction, such as tiles, panels, bricks, and other products in the construction industry. This research demonstrates that fly ash from the thermal power plant REK Bitola, Republic of North Macedonia, can be successfully used not only in cement production but also as potential raw materials for glass-ceramics production.

\section{REFERENCES}

[1] R. S. Blissett, N. A. Rowson, A review of the multicomponent utilization of coal fly ash, Fuel 97, 1-23 (2012). DOI: https://doi.org/10.1016/j.fuel.2012.03.024

[2] ECOBA, www.ecoba.com, accessed January 2021
[3] S. Kramar, L. Žibret, E. Fidanchevska, V. Jovanov, B. Angjusheva, V. Ducman, Use of fly ash and phosphogypsum for the synthesis for belite-sulfoaluminate clinker, Mater.de Const. 69, (333), e176, (2019). DOI: https://doi.org/10.3989/mc.2019.11617

[4] M. L. Zeggar, N. Azline, N. A.Safiee, Fly ash as supplementry material in concrete: A review, IOP Conf. Series: Earth and Environ. Sci. 357, 012025 (2019). DOI:10.1088/1755-1315/357/1/012025

[5] https://www.esm.com.mk/?page_id=110, accessed January 2021.

[6] B. Angjusheva, Production and characterization of glassceramics from waste materials, Quality of life, 2, (1-2) 13-20 (2011). DOI: 10.7251/QOL1101013A

[7] D. Bortoluzzi, L. Rodrigeues, A. M. Bernardin, Inertization of Coal Ashes by the Vitrification Technique: A Mixture design Approach, Miner. Process Extr. M. 34, 202-209 (2013). DOI: 10.1080/08827508.2012.656778

[8] S. Boycheva, D. Zgureva, V. Vassilev, Kinetic and thermodynamic studies on the thermal behaviour of fly ash from lignite coals, Fuel 108, 639-646 (2013). DOI: https://doi.org/10.1016/j.fuel.2013.02.042

[9] J. Dávalos et al., Preparation of glass-ceramics materials from coal fly ash and rise husk ash: Microstructural, physical and mechanical properties, Bol. Soc. Esp. Cerám. Vidr. (2020).

DOI: https//doi.org/10.1016/j.bsecv.2020.02.002

[10] G. Yilmaz, Structural characterization of glass-ceramics made from fly ash containing $\mathrm{SiO}_{2}-\mathrm{Al}_{2} \mathrm{O}_{3}-\mathrm{Fe}_{2} \mathrm{O}_{3}-\mathrm{CaO}$ and analysis by FT-IR-XRD-SEM methods, J. Mol. Struct. 1019, 37-42 (2012). DOI: https://doi.org/10.1016/j.molstruc.2012.03.028

[11] S. Wang, C. Zhang, J. Chen, Utilization of coal fly ash for the production of glass-ceramics with unique performances: A Brief Review, J. Mater. Sci. Technol. 30, (12), 12081212 (2014). DOI:10.1016/j.jmst.2014.10.005

[12] R. D. Rawlings, J. P. Wu, A. R. Boccaccini, Glassceramics: Their production from wastes - A review, $J$. Mater. Sci. 41, 733-761 (2006).

DOI: https://doi.org/10.1007/s10853-006-6554-3

[13] L. Zeng, H. Sun, T. Peng, W. Zheng, The sintering kinetics and properties of sintered glass-ceramics from coal fly ash of different particle size, Res. Phys. 15, 102774 (2019).

DOI:https://doi.org/10.1016/j.rinp.2019.102774

[14] L. Barbieri, A. M. Ferrari, I. Lancellotti, C. Leonelli, J. M. Rincón, M. Romero, Crystallization of $\left(\mathrm{Na}_{2} \mathrm{O}-\mathrm{MgO}\right)$ $\mathrm{CaO}-\mathrm{Al}_{2} \mathrm{O}_{3}-\mathrm{SiO}_{2}$ glassy systems formulated from waste products, J. Am. Ceram. Soc. 83, 2515-20 (2000). DOI:10.1111/j.1151-1916.2000.tb01584.x

[15] DIN EN 106:1992, Ceramic tiles. Determination of chemical resistance. Unglazed tiles.

[16] G. Baldi, E. Cenerali, C. Leonelli, T. Manfredi, G. C. Pellacani, C. Sligardi, Effects of nucleating agents on diopside crystallization in new glass-ceramics for tileglaze application, J. Mater. Sci. 30, 3251-3255 (1995). DOI: https://doi.org/10.1007/BF01209246

[17] I. Rozenstrauha, D. Bajare, R. Cimdins, L. Berzina, J. Bossert, A. R. Boccaccini, The influence of various ad- 
ditions on a glass-ceramic matrix composition based on industrial waste, Ceram. Int. 32, 115-119 (2006). DOI: https://doi.org/10.1016/j.ceramint.2005.01.006

[18] M. R. Little, V. Adell, A. R. Boccaccini, C. R. Cheeseman, Production of novel ceramic materials from coal fly ash and metal finishing wastes, Resour. Conserv. Recycl. 52, (11) 1329-1335 (2008). DOI: https://doi.org/10.1016/j.resconrec.2008.07.017

[19] S. Ghosal, J. L. Ebert, S.A. Self, Chemical composition and size distributions for fly ashes, Fuel Process. Technol. 44, 81 1-3 (1995).

DOI: https://doi.org/10.1016/0378-3820(94)00115-A

[20] L. Barbieri, A. Karamanov, A. Corradi, I. Lancellotti, M. Pelino, J. Ma. Rincon, Structure, chemical durability and crystallization behavior of incenerator-based glassy systems, J. Non-Cryst. Solids, 354, 521-528 (2008). DOI: https://doi.org/10.1016/j.jnoncrysol.2007.07.080

[21] L. Barbieri, F. Bondiooli, I. Lancellotti, C. Leonelli, M. Montorsi, A. M. Ferrari, P. Miselli, The anothitediopside system: structural and devitrification study. Part II: Crystalinity analysis by the Rietveld - RIR method, J. Am. Ceram. Soc. 88, 11 3131-3136 (2005). DOI: https://doi.org/10.1111/j.1551-2916.2005.00578.x

[22] A. A. Francis, R. D. Rawlings, R. Sweeney, A. R. Boccaccini, Crystalization kinetic of glass particles prepared from a mixture of coal ash and soda lime cullet glass, J. Non-Cryst. Solids, 333, 187-193 (2004). DOI: https://doi.org/10.1016/j.jnoncrysol.2003.09.048

[23] M. Erol, S. Küçükbayrak, A. Ersoy-Meriçboyu, Comparison of the properties of glass, glass-ceramic and ceramic materials produced from coal fly ash. J. Hazard. Mater. 153, 418-425 (2008). DOI: https://doi.org/10.1016/j.jhazmat.2007.08.071
[24] A. Karamanov, M. Pelino. Induced crystallization porosity and properties of sintered diopslide and wollastonite glass-ceramics, J. Eur. Ceram. Soc. 28, 555-562 (2008).

DOI: 10.1016/j.jeurceramsoc.2007.08.001

[25] K. Ikeda, Y. Nakayama, K. Kaizu, H. Kinoshita, A. Yoshikawa, S. Ogawa, H. S. Kim, Development of highstrength fly ash glass ceramics: Influence of Additive on Material Properties, J. Solid. Mech. Mater. Eng. 1, 8 1017-1025 (2007). DOI: https://doi.org/10.1299/jmmp.1.1017

[26] F. Peng, K. Liang, A. Hu, H. Shao, Nano-crystal glassceramics obtained by crystalization of vitrified coal fly ash, Fuel 83, 1973-1977 (2004). DOI: https://doi.org/10.1016/j.fuel.2004.04.008

[27] M. A. Binhussain, M. Marangoni, E. Bernardo, P. Colombo, Sintered and glazed glass-ceramics from natural and waste raw material, Ceram. Int. 40, 3543-3551 (2014).

DOI: https://doi.org/10.1016/j.ceramint.2013.09.074

[28] A. Karamanov, M. Pelino, M. Salvo, I. Metekovits, Sintered glass-ceramics from incinerator fly ashes. Part II. The influence of the particle size and heat-treatment on the properties, J. Eur. Ceram. Soc. 23, 1609-1615 (2003). DOI: https://doi.org/10.1016/S0955-2219(02)00371-0

[29] P. Pisciella, S. Crisucci, A. Karamanov, M. Pelino, Chemical durability of glasses obtained by vitrification of industrial wastes, Waste Manag. 21, 1-9 (2001). DOI: $10.1016 / \mathrm{S} 0956-053 \mathrm{X}(00) 00077-5$

[30] D. H. Vu, K. S. Wang, J. H. Chen, B. X. Nam, B. H. Bac, Glass-ceramic from mixture of bottom ash and fly ash, Waste Manag. 32, 2306-2314 (2012). DOI: https://doi.org/10.1016/j.wasman.2012.05.040 